\title{
RNA interference- a novel approach for plant disease management
}

\author{
Anita Puyam ${ }^{1}$, Shikha Sharma ${ }^{1}$ and Prem Lal Kashyap ${ }^{2 *}$ \\ ${ }^{1}$ Department of Plant Pathology, Punjab Agricultural University, Ludhiana-141004 (Punjab), INDIA \\ ${ }^{2}$ ICAR-Indian Institute of Wheat \& Barley Research (IIWBR), Karnal-132001 (Haryana), INDIA \\ *Corresponding author. E-mail: anitapau6243@gmail.com
}

Received: October 6, 2016; Revised received: February 19, 2017; Accepted: August 8, 2017

\begin{abstract}
RNA interference (RNAi) is an incredible revolution in the field of functional genomics, a breakthrough in plant molecular genetics. This technology will generate enormous potential for engineering control of gene expression. The success of managing biotic stress using RNAi technology will prove to be biologically and environmentally safe. It is therapeutic in approach as the resistance induced by RNAi is triggered by ds RNA that results in silencing of specific genes before being translated in a homology dependent manner. Over the time, RNAi is significantly proving it as one of the most promiscent management strategy which eliminates certain risks associated with the development of transgenic plants. This review gives an insight into the probability of management of plant diseases caused by various biotic agents viz. fungi, bacteria and viruses using RNA interference technique and hostpathogen related targeted sites.
\end{abstract}

Keywords: Diseases, Functional genomics, Gene Expression, Management, RNAi

\section{INTRODUCTION}

RNA interference (RNAi) is a conserved regulatory mechanism of gene expression that has been recently characterized in plants and invertebrates. It is a homology-dependent nucleotide sequence specific process of mRNA degradation or translation inhibition at the post -transcriptional level or epigenetic modification at the transcriptional level depended on RNA-directed DNA methylation (RdDM in plants) (Duan et al., 2012). It refers collectively to diverse RNA based processes that result in sequence specific inhibition of gene expression at the transcriptional or translational level (Fagwalawd et al., 2013). Once RNAi is triggered in a certain cell, a mobile signal is produced and spread through the whole plant causing the entire plant to be silenced (Broglie et al., 1991). RNAi has rapidly gained importance as a reverse genetics tool to knock down expression of targeted genes in plants, lower animals and micro-organisms (Senthil-Kumar and Mysore, 2010).This technology has been widely applied to alter the gene expression in plants with an aim to achieve desirable traits. RNAi has been used for enhancing the crop yield and productivity by manipulating the gene involved in biomass production, grain yield and enhanced shelf life of fruits and vegetables and nutritional improvements of crops (International service for acquisition of agri-biotech applications, Personal communication,2012).Besides, being a key regulator of important plant processes like growth, development and response to various stresses (Singh, 2005), it has also been applied for developing re- sistance against various biotic (bacteria, fungi, viruses, nematodes, insects) (Singh, 2005) and abiotic stresses (drought, salinity, cold etc.) (Khraiwesh et al., 2012). Mann et al., 2008, reviewed the technology as an ecofriendly approach for plant disease management. Further study of genetic host though therapeutic tools based on current molecular biology and biotechnological methods are exploited and their utilization by introgression, pyramiding, and development of transgenics have been well understood (Sanghera et al., 2011). This review discusses the mechanism, approaches to induce RNAi and the wide prospects of RNAi and limitations of the technology in managing plant pathogens.

Bio-chemical core of RNAi -small RNA, Dicers and Argonautes: The diverse RNA- based process that all results in degradation of target homologous mRNA based on complementary base pairing, share the common bio-chemical features. The substrate for RNAi mainly double-stranded (ds) RNA can be generated and single-stranded (ss) RNA can be processed through a diverse pathways resulting in transcriptional cleavage or regulation in post-transcriptional regulation. The pathway is built over the Dicer- Argonaute core that executes a diverse set of single stranded (ss) RNA- directed biological functions in higher plants and all the diverse mechanisms have a common biochemical core (Brodersen and Voinnet, 2006) as mention below:

Presence of a double-stranded dsRNA; this can be an introduced transgene, a rogue genetic element or a viral intruder that triggers the RNAi pathway of cell. 
Processing of dsRNA to small(s) 20-25nt dsRNAs with staggered ends; cleaving of the dsRNA into short, 20-26 basepairs long, fragments, called small interfering RNA (siRNA).

Inhibitory action of a selected ssRNA strand within effector complexes acting on partially or fully complementary RNA or DNA; identification between the two siRNA strands as either sense or antisense and degradation of the sense strands (with exactly the same sequence as the target gene).

Mechanism of RNA interference: RNA silencing is triggered by ds RNA that results in silencing of specific genes before being translated in a homology dependent manner. The entry of long dsRNA such as an introduced transgene, a rogue genetic element or a viral intruder is needed to trigger the RNA silencing. This recruits host ribonuclease -III like enzyme called Dicer with distinctive ds RNA binding, RNA helicase, RNase III and PAZ (Piwi/ Argonaute/ Zwille) domains (Brodersen and Voinnet, 2006). Dicer binds to long dsRNA and then cleaved into small interfering RNAs (si RNAs) of 21-25 nucleotides (nt) in length (Zrachya et al., 2007). Small interfering RNAs (siRNAs) mediate the selective degradation of target RNA by guiding a multi-component RNAse (Pandolfini et al., 2003), RNA-induced silencing complex (RISCs). It is a multicomplex protein consisting of a member of Argonaute (Ago) protein family. Ago protein contains two domains: PAZ domain- siRNA binding domain and PIWI domain- that provides endonucleolytic (slicer) activity to those RISCs programmed to cleave target RNAs (Brodersen and Voinnet, 2006). RISCs distinguish the siRNA strands as either sense / antisense. Finally, RISC target homologous mRNA for cleavage and degradation of sense strand based on complementary base pairing (Baulcombe, 2004). The antisense strands in the RISC guided to target mRNA in a sequence specific manner. The activated RISC thus participates repeatedly in mRNA degradation inhibiting protein synthesis (Brodersen and Voinnet, 2006). The Dicer-Ago core executes a diverse set of ssRNA directed biological function in higher plants (Brodersen and Voinnet, 2006).

Approaches to induce RNAi: Resistance through RNAi in plants has been achieved by expressing hpRNA that folds back to create a dsRNA in vivo (Wesley et al., 2001), delivering artificial micro (mi) RNA (Schwab et al., 2006) or by directly delivering RNA silencing molecules into plant tissues (Tenllado and Diaz-Ruiz, 2001).The hairpin inverse repeat sequences from viral genomes can be small hpRNA, selfcomplementary hpRNA, and intron-spliced hpRNA. Among these methods, self complementary hpRNAs separated by an intron likely elicit post- transcriptional gene silencing (PTGS) with highest efficiency (Smith et al., 2000 and Wesley et al., 2001). For delivering artificial micro-RNAs (miRNAs), they are designed to mimic the intact secondary structure of endogenous miRNA precursors and processed in vivo to target genes of interest (Duan et al., 2012).

Another approach is the mechanical inoculation of in vitro synthesized dsRNA or the Agrobacteriummediated transient expression of dsRNA in plants, and effective resistance to sequence homologous viruses (Tenllado and Diaz-Ruiz., 2001). However, major challenge for researchers is to deliver specific short sequence of target gene that will trigger the RNAi pathway in plants. A number of methods have been used to deliver the active molecules into the plant. Among them, the most reliable and commonly exploited approaches are:

Virus-induced gene silencing (VIGS): Homologybased defense mechanisms triggered by incoming viruses to target individual genes for silencing in a process called virus-induced gene silencing (VIGS). But in the present era VIGS is synonymous to a virus based functional genomics tool to knockdown the host gene for understanding its function. Maloy (2005) defined it as 'When dsRNA molecules produced during viral replication trigger gene silencing, the process is called VIGS'. VIGS has been reported as the most popular approach for inducing genetic activity in plants. In this method, either RNA/ DNA viruses have been modified as vectors to silence endogenous plant genes. For the process, cloning homologous gene fragments into the virus without compromising viral replication and movement is aberrant / transgene coded RNAs required (Wani et al., 2010) .The viral replication in plants generates dsRNA molecules that triggers PTGS response in plants. This results in reduction of virus titres in local and distant leaves and plant recovery phenotype. VIGS has been first demonstrated in RNA viruses by inserting sequence into TMV (Brunt et al., 1996). But it will be wrong to say that all RNA virusderived expression vectors to be as silencing vectors because many have potent anti-silencing proteins such as TEV, that directly interfere with host silencing machinery (Palmer and Rybicki, 2001; Kumagai et al., 1995). Similarly, DNA viruses have not been used extensively as expression vectors due to their size constraints for movement (Kjemtrup et al., 1998). But the most promising vector is Maize streak virus (MSV) derived vector which has been successfully used for long -term production of protein in maize cell cultures (Kumagai et al., 1995). In the area of functional genomics VIGS are the new tools. They can be exploited to study the different processes i.e plant development, host- pathogen interaction, host- nematode interaction, host- insect interactions. Scofield et al. (2005) have successfully exploited the VIGS- BSMV based system for the first time in monocots to study the functional analysis of Lr21 mediated leaf rust resistance pathway (Chuang and Meyerowtiz, 2000). This VIGS strategy can confer high resistance but the efficacy varies from 
Table 1. Targeted region of RNAi in some fungal plant pathogens.

\begin{tabular}{lll}
\hline Pathogen & Targeted region & References \\
\hline Magnaporthe oryzae & eGFP & Kadotani et al.(2003) \\
Cladosporium falvum & cgll and cgl2 & Segers et al. $(1999)$ \\
F. oxysporum f. sp. conglutinans & FOW2, FRP1 and OPR & Zongli et al. $(2015)$ \\
Blumeria graminis f.sp. tritici & Rnr & Dimitar et al. $(2014)$ \\
Blumeria graminis & Mlo & Schweizer et al. $(2000)$ \\
Venturia inaequalis & Multiple inverted repeats & Fitzgerald et al. $(2004)$ \\
\hline
\end{tabular}

Table 2. Targeted region of RNAi in various plant-virus systems.

\begin{tabular}{|c|c|c|c|}
\hline Virus & Plant host system & Targeted Region & References \\
\hline $\begin{array}{l}\text { African cassava } \\
\text { mosaic virus }\end{array}$ & $\begin{array}{l}\text { N. benthamiana, } \\
\text { M. esculenta }\end{array}$ & $p d s$, su, cyp $79 d 2$ & Fofana et al., 2004 \\
\hline $\begin{array}{l}\text { Tobacco } \\
\text { mosaic virus }\end{array}$ & $\begin{array}{l}\text { N. benthamiana, } \\
\text { N. tabacum }\end{array}$ & $p d s, p s y$ & Kumagai et al, 1995 \\
\hline $\begin{array}{l}\text { Tomato bushy } \\
\text { shunt virus }\end{array}$ & N. benthamiana & $g f p$ & Hou and W. Qiu, 2003 \\
\hline Potato virus $X$ & $\begin{array}{l}\text { N. benthamiana, } \\
\text { S. tuberosum }\end{array}$ & $p d s, g f p$ & $\begin{array}{l}\text { Ruiz et al., } 1998 \text { Faivre- } \\
\text { Rampant et al., } 2004\end{array}$ \\
\hline $\begin{array}{l}\text { Poplar mosaic } \\
\text { virus }\end{array}$ & N. benthamiana & $g f p$ & Naylor et al., 2005 \\
\hline $\begin{array}{l}\text { Aquilegia Tobacco } \\
\text { rattle virus Rar1, EDS1, } \\
\text { NPR1/NIM1 }\end{array}$ & $\begin{array}{l}\text { N. benthamiana, } \\
\text { Arabidopsis, } \\
\text { tomato, Solanu mspecies, } \\
\text { Chilli pepper, opium poppy }\end{array}$ & $p d s, r b c S, g f p$ & $\begin{array}{l}\text { Ratcliff et al., 2001; Gould and } \\
\text { Kramer, } 2007\end{array}$ \\
\hline $\begin{array}{l}\text { Tomato bushy } \\
\text { shunt virus }\end{array}$ & N. benthamiana & $g f p$ & Hou et al., 2003 \\
\hline $\begin{array}{l}\text { Tomato yellow } \\
\text { leaf curl China } \\
\text { virus-associated } \\
\text { b DNA satellite }\end{array}$ & $\begin{array}{l}\text { N. benthamiana, } \\
\text { Lycopersicon } \\
\text { esculentum } \\
\text { N. glutinosa,N. tabacum }\end{array}$ & $\begin{array}{l}\text { pcna,pds, } \\
\text { su, gfp }[\end{array}$ & Tao et al., 2004 \\
\hline $\begin{array}{l}\text { Tomato golden } \\
\text { mosaic virus }\end{array}$ & N. benthamiana & su, luc & Peele et al.,2001 \\
\hline $\begin{array}{l}\text { Satellite tobacco } \\
\text { mosaic virus] }\end{array}$ & $\begin{array}{l}\text { Nicotiana } \\
\text { Tabacum }\end{array}$ & Several genes & Gossele et al.,2002 \\
\hline Brome mosaic virus & Barley, rice, Maize & pds, actin 1, rubisco activase & Ding et al., 2006 \\
\hline $\begin{array}{l}\text { Pea early } \\
\text { browning virus }\end{array}$ & P. sativum & pspds, uni, kor & Constantin et al., 2004 \\
\hline $\begin{array}{l}\text { Barley stripe } \\
\text { mosaic virus }\end{array}$ & Barley, wheat & $P d s$ & Cakir and Tor, 2010 \\
\hline $\begin{array}{l}\text { Bean pod } \\
\text { mottle virus }\end{array}$ & Soybean & Pds Actin & Zhang and Ghabrial, 2006 \\
\hline $\begin{array}{l}\text { Cabbage leaf } \\
\text { curl virus }\end{array}$ & Arabidopsis & $g f p, C H 42, p d s$ & Turnage, 2002 \\
\hline
\end{tabular}

virus to virus, delayed infection recovery from infection or low resistance (Chuang and Meyerowtiz, 2000; Liu et al., 2002). It has been reported that homologous viruses with sequence mutation rates of over approximately $10-20 \%$ in comparision to the transgene source virus will overwhelm the resistance mechanism and result in the infection (Dalmay et al., 2000). At the same time, the plant is invaded by a complex of diverse pathogen sources in the field. One motive of high resistance should not be against a single virus but to the multiple viruses. So, that multiple viruses can simultaneously be tangled and achieved a broader resistance. For this purpose, transgenic plants with multiple hpRNA constructs form multiple viral sources or a single hpRNA construct pyramided with different viral sequence need to be created (Wani et al., 2010).

Agro-infiltration: Agro-infiltration is a strategy to induce a transient RNA silencing system to directly deliver the RNA silencing molecules into plant tissues (Duan et al., 2012). This will overcome the growing bio-safety issues due to transgenic plants created for RNA silencing. The injection of Agrobacterium carrying similar DNA constructs into the intracellular spaces of leaves for triggering RNA silencing is known as agro-inoculation or agro-infiltration (Hily and Liu, 2007). The simple mechanism for inducing RNAi is similar to the strategy for transient expression of $\mathrm{T}$ DNA vectors after delivery by Agrobacterium tumefaciens (Zrachya et al., 2007). The transient plants were then transformed with $A$. tumefaciens genes harboring 
the gene of interest for inducing RNAi as in the case of Tomato plants cv. Micro-Tom transformed with $A$. tumefaciens Gv3101/ PMP90kk harbouring plasmid pMon RNAi CP (Fillati et al., 1987; Singh, 2005). They provide an efficient way for achieving a downregulation of green fluorescent protein (GFP) expression in Nicotiana benthaniana. This results from agroinfiltration of the coat protein (CP) silencing construct followed by infiltration of a fused GFP-CP (Fagwalawd et al., 2013). Besides, it has been successfully used for triggering the gene iaaM and ipt responsible for inducing resistance to crown gall disease in apple (Dunoyer et al., 2007), OSGEN-1-green fluorescent fusion protein in rice (Moritoh et al.,2005) and hpGUS in different transgenic lettuce lines (Wroblewski et al., 2007). Agro-infiltration assay was successfully used for screening candidate signaling components required for the activation of R-gene mediated disease resistance in $N$. benthamiana and tomato (Persengiev et al., 2004; Yuan et al., 2004). There have been reports of transient silencing of the grapevine gene VvPGIPI encoding a polygalacturonase inhibiting protein (PGIP) by agroinfiltration with a construct for RNAi (Bertazzon et al., 2012).

Micro-bombardment: Direct introduction of a plasmid producing hpRNA by particle bombardment method has been used for transient gene silencing of glutathione synthetase (GSHS) in somatic embryos of Camellia sinensis-L (Mohanpuria et al., 2008). The technique involved the mechanical inoculation of in vitro synthesized ds RNA which mimicks the intact secondary structureof endogenous miRNA precursors. In this strategy, biolistic pressure is used to deliver particles coated with dsRNA /siRNA or DNA encoding hairpin sense /antisense RNA construct into plants. This triggers the silencing of GFP expression (Wani et al., 2010) thus activating RNAi pathway.

An easy way of delivering the resistance through RNAi needs to be standardized. Some researchers has formulated a new approach which involved the utilization of the bacterial system to biosynthesize dsRNA in vivo and crude extracts by inoculating into plants via spraying (Yin et al., 2010 and Gan et al., 2010). This approach could be a cost-effective and will require less skill but needs to be standardized for adoption of the technique widely.

RNAi in plant disease management: RNAi technology has emerged as one of the promising strategy for enhancing resistance in plants to tackle the biotic stresses caused by fungal, bacterial, viral and nematode diseases that causes huge losses in important agricultural crops (Singh, 2005). Some remarkable and plausible examples of the application of this techniquein disease management have been discussed below:

RNA silencing-mediated resistance to plant fungal pathogens: Most plant fungal pathogens interact with their corresponding host through a highly specialized cell called a haustorium. This structure is surrounded by extra-haustorial matrix bordered by plants and fungal membranes on either side. Besides facilitating signal exchange and nutrient uptake, this also points to the possibility of trafficking of dsRNA or siRNA from host plants into the fungal pathogens to trigger RNA silencing mediated resistance (Duan et al., 2012). If silencing signals generated in the host cell can cross this exchange and barrier, gene silencing may trigger in haustorial cells and possibly interferes with pathogenesis or other metabolic process (Yin et al., 2011). This type of gene silencing is known as Host-induced gene silencing (HIGS). HIGS has been reported in barley powdery mildew fungi Blumeria graminis(Nowara et al., 2010). Development of host induced RNAi system has also been reported in wheat stripe rust fungus ( Puccinia striiformis f.sp. tritici) where gene fragments from the rust fungi Puccinia striiformis f.sp. tritici or P.graminis f.sp. tritici were delivered to plant cells through Barley stripe mosaic virus system and some reduced the expression of the corresponding genes in the rust fungus. This is associated with fungal gene expression patterns (Yin et al., 2011). This reduction was detected in transcripts with relatively high levels of expression in fungal haustoria. The results proven in fungi indicated that RNAi approach can be used as tool for functional genomics, aimed at modification of gene expression. Homology based gene silencing induced by transgenes (co-suppression), antisense or dsRNA has been demonstrated in many plant pathogenic fungi including Cladosporium fulvum (Segers et al., 1999; Schweizer et al., 2000). Venturia inaequalis (Fitzgerald et al., 2004), Magnaporthe oryzae (Kadotani et al., 2003), Neurospora crassa (Romano et al.,1992)and Puccinia striiformis (Yin et $a l ., 2011)$. The targeted region for gene-silencing has been described in table 1 .

RNA silencing-mediated resistance to plant pathogenic bacteria: Escobar et al. (2001) for the first time documented RNAi application for engineering resistance in plant against bacterial pathogen causing crown gall disease. In the particular disease, iaaM and ipt oncogenes are responsible for tumourogensis (gall formation) and a pre-requisite for tumour formation. The management strategy of the disease targets these oncogenes.,With the help of RNAi technology, they showed that transgenic plants (Arabidopsis thaliana and Lycopersicon esculentum) containing modified construct of these two bacterial genes (s) showed resistance against crown gall. The transgenic genes shut down the expression of iaaM and ipt oncogenes of the incoming bacterial pathogen, thereby disturbing the hormonal production and ultimately, tumourogenesis process after infection. Dunoyer et al., 2007 also reported that plants lacking the modified oncogenes were 
hyper-susceptible to A.tumefaciens. Another example is the RNAi-mediated enhanced resistance to Xanthomonas oryzae, the leaf blight bacterium due to successful knockdown of a rice homolog of OsSSI2 (Jiang et al., 2009). Zhai et al., 2011 and Li et al., 2012 studied the function of several miRNA families target genes of plant innate immune receptors (NBS-LRR) in Legumes and Solanaceae, respectively. They gave a new insight into viral and bacterial infection in plants that suppresses miR482- mediated silencing of $R$ genes. Considering the findings from different researchers (Jiang et al., 2009; Zhai et al., 2011 and Li et al., 2012), a general understanding can be drawn that miRNA can either act as up-or down- regulators of the bacterial invasion. The pathogen responsive miRNA effects the gene expression either by suppression of negative regulators or up regulation of the positive factors required for immune responses. Identification and characterization of pathogen responsive miRNAs that induced positive regulators of bacterial resistance, will open a flood gate to enhancement of transgenic plants that will involve the constitutive over- expression of miRNA or a miRNA.

RNA silencing-mediated resistance to plant virus: Waterhouse et al., 1998 first demonstrated the effectiveness of RNAi technology for generating virus resistance in potato against Potato virus $Y$, harbouring vectors for simultaneous expression of both sense and antisense transcripts of the helper-component proteinase (HC-Pro) gene. RNA components of the silencing pathways such as single strand template RNA, dsRNA and / or siRNA are the preferred targets of most viral suppressors. However, Wani et al., 2010 reported counter-silencing mechanism in viruses against plant viruses by encoding proteins that can overcome such posed resistance. Pandolfini et al (2003) observed the expression of self-complementary hairpin RNAs within two complementary regions separated by an intron elicits PTGS with high efficiency as in case of Plum pox virus. The hairpin construct ihprolC-pp 197 gene of PPV RNA genome (a 197 bp sequence) is controlled by the rol $C$ promoter. The transgenic $N$. benthamiana plants for ihprol C-pp197 contain siRNAs homologous to the 197bp sequence and its progenies were resistant to Plum pox virus infection (Pandolfini et al., 2003). Against DNA viruses, the phenomenon is rarely reported as compared to the RNA viruses. Infection with the homologous geminivirus could be silenced by a geminiviral promoter the DNA virus group (Seemanpillai et al., 2003). Bombardment with a $h p R$ $N A$ construct containing the promoter sequence of geminivirus Vigna mungo yellow mosaic virus (VMYMV) in black gram (Vigna mungo) leaves under the control of the $35 S$ promoter, showed the recovery of plants completely from the VMYMV infection (Pooggin et al., 2003), suggesting the effectiveness of
RNA silencing strategy by engineering resistance to DNA viruses. Bean golden mosaic virus (BGMV) can also suppressed by the expression of a $h p R N A$ transgenic derived from a replicase coding sequence $A C I$ (Aragao and Faria, 2009). Table 2 shows some other reports of RNAi in various plant-virus systems.

\section{Conclusion}

Application of RNAi in management of biotic stress will be proved to be an incredible revolution in the field of functional genomics and a breakthrough in plant molecular genetics. If RNAi technology is developed successfully and employed for management of major diseases on commercial scale, they can prove to be an eco-friendly and biologically safe technology. Moreover, this technique eliminates the risk associated with development of transgenics and it will also generate enormous potential for engineering control of gene expression. An agronomically superior cultivar can be engineered for additional plant fitness by using RNAi technology. However, selection of targeting sequence and deliver of siRNA is a major challenge for plant molecular biologists. More understanding and exploration in the field of RNAi promoting resistance is needed. Therefore, further molecular research is needed to unfurl the factors affecting RNAi-mediated resistance and solved all the challenges in delivering the siRNA to the host system and identifying the targeted region to effectively overcome the pathogen and promote crop improvement.

\section{REFERENCES}

Aragao, F.J.and Faria, J.C. (2009). First transgenic geminivirus-resistant plant in the field. Nat. Biotechnol., 27:1086-1088.

Baulcombe D. (2004). RNA silencing in plants. Nature.431: 356-63.

Bertazzon, N., Raiola, A., Castiglioni, C. ,Gardiman, M., Angelini, E., Borgo, M. and Ferrari, S. (2012). Transient silencing of the grapevine gene VvPGIP1 by agroinfiltration with a construct for RNA interference.Plant Cell Rep., 31:133-43.

Brodersen P., and Voinnet O. (2006). The diversity of RNA silencing pathways in plants. Trends Genet. 22: 268-80.

Broglie, K.I., Chet, M., Holliday, M.N. (1991). Transgenic plants with enhanced resistance to fungal pathogen Rhizoctonia solani. Science, 254: 1194.

Brunt, A.A., Crabtree, K., Dallwitz, M.J., Gibbs, A.J., Watson, L. and Zurcher, E.J. (1996). Plant viruses online: descriptions and lists from the VIDE database. 2011-04 -20 .http://biology. anu. edu. au/Groups/MEs/vide.

Cakir C. and Tör, M. (2010) Factors Influencing Barley Stripe Mosaic Virus-Mediated Gene Silencing in Wheat. Physiol. Mol. Plant Pathol. 74: 246-253.

Chuang, C.F. and Meyerowtiz, E.M. (2000). Specific and Heritable Genetic Interference by Double-Stranded RNA in Arabidopsis thaliana. PNAS, 97:4985- 4990.

Constantin, G. D., Krath, B. N., MacFarlane, S. A., Nicolaisen, M., Johansen, I. E. and Lund, O. S. (2004) Virus 
-Induced Gene Silencing as a Tool for Functional Genomics in a Legume Species. Plant J., 40: 622-631.

Dalmay, T., Hamilton, A.J., Mueller, E. and Baulcombe, D.C. (2000). Potato Virus X Amplicons in Arabidopsis Mediate Genetic and Epigenetic Gene Silencing. PlantCell 12:369-380.

Dimitar, D., Stefanie, L., Annika, J., Daniela, Axel, H., Jeyaraman, R., Nils, S., Rajiv, S., Benjamin, K. and Patrick, S. (2014). Discovery of genes affecting resistance of barley to adapted and non-adapted powdery mildew fungi. Genome boil., 15:518.

Ding, X. S., Schneider, W. L., Chaluvadi, S. R., Rouf Mian, R. M. and Nelson, R. S. (2006) Characterization of a Brome Mosaic Virus Strain and Its Use as a Vector for Gene Silencing in Monocotyledonous Hosts. Mol. Plant -Microbe Interact., 19: 1229-1239.

Duan, C.G.,Wang, C.H. and Guo, H.S. (2012). Application of RNA silencing to plant disease resistance. Silence, 3: $1-8$.

Dunoyer, P., Himber, C., Ruiz-Ferrer, V., Alioua, A. and Voinnet, O. (2007). Intra- and Intercellular RNA Interference in Arabidopsis thaliana Requires Components of the MicroRNA and Heterochromatic Silencing Pathways. Nat.Genet., 39:848-856.

Escobar, M.A., Civerolo, E.L., Summerfelt, K.R. and Dandekar, A.M. (2001). RNAi-mediated oncogene silencing confers resistance to crown gall tumorigenesis. PNAS, 98:13437-13442.

Fagwalawd, I.D., Kutama, A.S., Yakasai, M.T. (2013). Current issues in plant disease control: biotechnology and plant disease. Bajopas, 6: 121-126.

Faivre-Rampant, O., Gilroy, E. M., Hrubikova, K., Hein, I. Millam, S., Loake, G. J., Birch, P., Taylor, M. and Lacomme, C. (2004) Potato Virus X-Induced Gene Silencing in Leaves and Tubers of Potato. Plant Physiol., 134: 1308-1316.

Fillati, J.J., Kiser, J., Rose, R. and Comai, L. (1987). Efficient transfer of a glyphosate tolerance gene into tomato using a binary Agrobacterium tumefaciens vector. Biotechnol., 5: 726-730.

Fitzgerald, A., Van, Kha, J.A. and Plummer, K.M. (2004). Simultaneous Silencing of Multiple Genes in the Apple Scab Fungus Venturia inaequalis, by Expression of RNA with Chimeric Inverted Repeats. Fungal Genet.Biol., 41: 963-971.

Fofana, I. B., Sangare, A., Collier, R., Taylor, C. and Fauquet, C. M. (2004) A Geminivirus-Induced Gene Silencing System for Gene Function Validation in Cassava. Pl. Mol. Biol., 56: 613-624

Gan, D., Zhang, J., Jiang, H., Jiang, T., Zhu, S. and Cheng, B. (2010). Bacterially expressed dsRNA protects maize against SCMV infection.Plant Cell Rep., 29: 1261-1268.

Gossele, V. V., Fache, I. I., Meulewaeter, F., Cornelissen, M. and Metzlaff, M. (2002) SVISS-a Novel Transient Gene Silencing System for Gene Function Discovery and Validation in Tobacco. The. Plant. J., 32: 859- 866.

Gould, B. and Kramer, E. M. (2007) Virus-Induced Gene Silencing as a Tool for Functional Analyses in the Emerging Model Plant Aquilegia (columbine, Ranunculaceae). BMC Plant Methods, 12: 6.

Hily, J.M. and Liu, Z. (2007). An Overview of Small RNAs. In: Bassett, C, L.( eds). Regulation of Gene Expression in Plants. Springer-Verlag, Berlin. pp. 123-147.

Hou, H. and Qiu, W. (2003) A Novel Co-Delivery System Consisting of a Tomato Bushy Stunt Virus and a Defective Interfering RNA for Studying Gene Silencing," J. Virol. Methods, 111: 37-42.

International service for acquisition of agri-biotech applications (2012). Pocket K No. 34: RNAi for Crop Improvement. Available Source: http://isaaa.org/resources/ publications/pocketk/34/default.asp

Jiang, C.J., Shimono, M., Maeda, S., Inoue, H., Mori, M., Hasegawa, M., Sugano, S. and Takatsuji, H. (2009). Suppression of the rice fatty-acid desaturase gene OsSSI2 enhances resistance to blast and leaf blight diseases in rice. Mol. Plant-Microbe Interact., 22: 820-829.

Kadotani, N., Nakayashiki, H.,Tosa, Y. and Mayama, S. (2003). RNA Silencing in the Pathogenic Fungus Magnaportheoryzae. Mol. Plant-Microbe Interact., 16:769776 .

Khraiwesh, B., Zhu, J.K. and Zhu, J. (2012). siRNAs in biotic and abiotic stress responses of plants.Biochim. Biophys. Acta, 1819: 137-148.

Kjemtrup. S., Sampson, K.S., Peele, C.G., Nguyen, L.V. and Conkling, M.A. (1998). Gene Silencing from Plant DNA Carried by a Geminivirus. Plant J., 14:91-100.

Kumagai, M. H., Donson, J., della-Cioppa, G., Harvey, D., Hanley, K. and Grill, L. K. (1995) Cytoplasmic Inhibition of Carotenoid Biosynthesis with Virus-Derived RNA. Proceedings of the National Academy of Sciences of the USA. 92: 1679-1683.

Li, X., Wang, X., Zhang, S., Liu, D., Duan, Y. and Dong, W. (2012). Identification of soybean microRNAs involved in soybean cyst nematode infection by deep sequencing. PLOS ONE doi:10.1371/journal.pone. 0039650.

Liu, Y.L., Schiff, M. and Dinesh-Kumar S.P. (2002). Virus Induced Gene Silencing in Tomato. Plant J.31:777-786.

Maloy, O.C. (2005). Plant disease management. Plant Instructor. D01:10 1094/PHL - 1 - 2005- 0202 - 01.

Mann, S.K., Kashyap, P.L., Sanghera, G.S., Singh, G. and Singh, S. (2008). RNA Interference: An eco-friendly tool for plant disease management. Transgen. Plant J., 2:110-126

Mohanpuria, P., Rana, N. and Yadav, S. (2008). Transient RNAi based gene silencing of glutathione synthetase reduces glutathione content in Camellia sinensis(L.) O. Kuntze somatic embryos. Biol. Plant., 52: 381-384.

Moritoh, S., Miki, D., Akiyama, M., Kawahara, M., Izawa, T., Maki, H. and Shimamoto, K. (2005). RNAimediated silencing of OsGEN-L (OsGEN-like), a new member of the RAD2/XPG nuclease family, causes male sterility by defect of microspore development in rice. Plant Cell Physiol., 46:699-715.

Naylor, M., Reeves, J., Cooper, J. I., Edwards, M. L. and Wang, H. (2005) Construction and Properties of a Gene Silencing Vector Based on Poplar Mosaic Virus (Genus Carlavirus). J. Virol. Methods, 124: 27-36

Nowara D., Gay, A., Lacomme, C., Shaw, J., Ridout, C., Douchkov, D., Hensel, G., Kumlehn, J., Schweizer, P. (2010). HIGS: Host Induced gene silencing in the obligate biotrophic fungal pathogen Blumeria graminis. Plant Cell., 22: 3130-3141.

Palmer, K.E. and Rybicki, E.P. (2001). Investigation of the potential of maize streak virus to act as an infectious gene vector in maize plants. Arch. Virol., 146:1089- 
1104.

Pandolfini, T., Molesini, B., Avesani, L., Spena, A. and Polverari, A. (2003). Expression of self-complementary hairpin RNA under the control of the rolC promoter confers systemic disease resistance to Plum pox virus without preventing local infection. $B M C$ Biotechnol., 3:7.

Peele, C., Jordan, C.V., Muangsan, N., Turnage, M., Egelkrout, E., Eagle, P., Hanley-Bowdoin, L. and Robertson, D. (2001) Silencing of a Meristematic Gene Using Geminivirus-Derived Vectors. Plant J., 27: 357366.

Persengiev, S. P., Zhu, X. and Green, M.R. (2004).Nonspecific, concentration-dependent stimulation and repression of mammalian gene expression by small interfering RNAs (siRNAs). RNA, 10: 12-18.

Pooggin, M.., Shivaprasad, P.V., Veluthambi, K. and Hohn, T. (2003). RNAi targeting of DNA virus in plants. Nat. Biotechnol., 21:131-132.

Ratcliff, F., Martin-Hernandez, A. M. and Baulcombe, D. C. (2001) Tobacco Rattle Virus as a Vector for Analysis of gene Functions by Silencing. Plant J., 25: 237-245.

Romano, N. and Macino, G. (1992). Quelling: transient inactivation of gene expression in Neurospora crassa by transformation with homologous sequences. Mol. Microbiol., 6:3343-3353.

Ruiz, M. T., Voinnet, O. and Baulcombe, D. C. (1998) Initiation and Maintenance of Virus-Induced Gene Silencing. Plant Cell, 10: 937-946.

Sanghera, G. S., Kashyap, P. L., Singh, G., Teixeira da Silva, J.A. (2011).Transgenics: fast track to plant stress amelioration. Transgen. Plant., J.5:1-26.

Schwab, R. (2006). Highly Specific Gene Silencing by Artificial MicroRNAs in Arabidopsis. Plant Cell, 18:11211133.

Schweizer, P., Pokorny, P., Schulze-Lefert, P. and Dudler ,R .(2000). Double Stranded RNA Interference with Gene Functions at the Single Cell in Cereals. Plant J., 24: 895-903.

Scofield, S.R., Huang, L., Brandt, A.S. and Gill, B.S. (2005). Development of a virus-induced gene-silencing system for hexaploid wheat and its use in functional analysis of the Lr21-mediated leaf rust resistance pathway. Plant Physiol., 138: 2165-2173.

Seemanpillai, M., Dry, I., Randles, J. and Rezaian, A. (2003). Transcriptional silencing of geminiviral promoter-driven transgenes following homologous virus infection. Mol. Plant-Microbe Interact., 16:429-438.

Segers, G.C., Hamada, W., Oliver, R.P. and Pspanu, P.D. (1999). Isolation and Characteristaion of Five Different Hydrophobin-Encoding cDNA from the Fungal Tomato Pathogen Cladosporium fulvum. Mol.Gen. Genet., 261:644-652.

Senthil-Kumar, M. and Mysore, K.S. (2010). RNAi in Plants: recent developments and applications in agriculture. Gene Silencing: Theory, Techniques and Applications, 83-199.

Singh, R.S. (2005). Introduction to Principles of Plant Pathology. Oxford and IBH Publishing Co. PVT. LTD., New Delhi. pp.178-189.

Smith, N.A., Singh, S.P., Wang, M.B., Stoutjesdijk, P.A.,
Green, A.G. and Waterhouse, P.M. (2000). Total silencing by intron-spliced hairpin RNAs. Nature, 407:319-320.

Tao, X. and Zhou, X. (2004) A Modified Viral Satellite DNA that Suppresses Gene Expression in Plants. The Plant J. 38: 850-860.

Tenllado, F. and Diaz-Ruiz, J.R. (2001). Double-stranded RNA-mediated interference with plant virus infection. J. Virol.75: 12288-12297.

Turnage, M. A., Muangsan, N., Peele, C. G. and Robertson, D. (2002) "Geminivirus-Based Vectors for Gene Silencing in Arabidopsis. The Plant J. 30: 107-117.

Wani, S. H., Sanghera, G.S. and Singh, N.B. (2010). Biotechnology and Plant Disease Control-Role of RNA Interference. Am. J. Plant Sci.1: 55-68.

Waterhouse, P.M., Graham, M.W. and Wang, M.B. (1998). Virus Resistance and Gene Silencing in Plants can be Induced by Simultaneous Expression of Sense and Antisense RNA. PNAS95: 13959-64.

Wesley,V., Helliwell, C., Smith, N., Wang, M., Rouse, D., Liu, Q., Gooding, P., Singh, S., Abbott, D., Stoutjesdijk, P., Robinson, S., Gleave, A., Green, A. and Waterhouse P (2001). Construct design for efficient, effective and high-throughput gene silencing in plants. Plant J. 27:581-590.

Wroblewski, T., Piskurewicz, U., Tomczak, A. and Ochoa Michelmore, R.W. (2007). Silencing of the major family of NBS-LRR-encoding genes in lettuce results in the loss of multiple resistance specificities. Plant J. 5:803818.

Yin, C., Jurgenson, J.E. and Hulbert, S.H. (2011). Development of a host-induced RNAi system in the wheat Stripe Rust Fungus Puccinia striiformis f.sp.tritici.Mol. Plant-Microbe Interact. 24: 554-561.

Yin, G.H., Sun, Z.N, Song YZ, An HL, Zhu CX, Wen FJ (2010). Bacterially expressed double-stranded RNAs against hot-spot sequences of tobacco mosaic virus or potato virus $\mathrm{Y}$ genome have different ability to protect tobacco from viral infection.Appl. Biochem. Biotechnol. 162:1901-1914.

Yuan, B., Latek, R., Hossbach, M., Tuschl, T. and Lewitter, F. (2004). siRNA Selection Server: an automated siRNA oligonucleotide prediction server. Nucleic Acids Res.32: 130-134.

Zhai, J., Jeong, D.H., DePaoli, E., Park, S., Rosen, B.D. and Li, Y. (2011). Micro RNAs as master regulators of the plant NB-LRR defense gene family via the production of phased, trans- acting siRNAs. Genes Dev. 25:2540 2553.doi: $10.1101 / \mathrm{gad} .177527 .111$

Zhang C. and Ghabrial, S. A. (2006) Development of Bean Pod Mottle Virus-Based Vectors for Stable Protein Expression and Sequence-Specific Virus-Induced Gene Silencing in Soybean. Virology 344: 401-411.

Zongli, H., Urvi, P., Natsumi, M., Yuri, T. and Jose, R.B. (2015) Downregulation of Fusariumoxysporum endogenousgenes by Host-Delivered RNAinterference enhances disease resistance. Frontiers in chem. 3: 1-10

Zrachya, A, Kumar, P.P., Ramakrishan, U., Levy, Y., Loyter, A., Arazi, T., Lapidot, M. and Gafni, Yedidya (2007). Production of siRNA targettance to the virused against TYlC coat protein transcripts lead to silencing expression and resisistance in virus. Transgenic Res. 16: $385-98$ 